\title{
TRPM8 downregulation by angiotensin II in vascular smooth muscle cells is involved in hypertension
}

\author{
FANG HUANG, MIN NI, JING-MING ZHANG, DONG-JIE LI and FU-MING SHEN \\ Department of Pharmacy, Shanghai Tenth People's Hospital, Tongji University, Shanghai 200072, P.R. China
}

Received November 3, 2015; Accepted December 8, 2016

DOI: $10.3892 / \mathrm{mmr} .2017 .6158$

\begin{abstract}
Angiotensin II (Ang II)-induced injury of vascular smooth muscle cells (VSMCs) serves an important role in hypertension and other cardiovascular disorders. Transient receptor potential melastatin 8 (TRPM8) is a thermally-regulated $\mathrm{Ca}^{2+}$-permeable channel that is activated by reduced body temperature. Although several recent studies have revealed the regulatory effect of TRPM8 in vascular tone and hypertension, the precise role of TRPM8 in dysfunction of vascular smooth muscle cells (VSMCs) induced by Ang II remains elusive. In the present study, the possible function of TRPM8 in Ang II-induced VSMCs malfunction in vivo and in vitro was investigated. In the aortae from rats that had undergone a two-kidney one-clip operation, which is a widely-used renovascular hypertension model, the mRNA and protein levels of TRPM8 were reduced. In addition, exogenous Ang II treatment decreased TRPM8 mRNA and protein expression levels in primary cultures of rat VSMCs. TRPM8 activation by menthol, a pharmacological agonist, in VSMCs, significantly attenuated the Ang II-induced increase in reactive oxygen species and $\mathrm{H}_{2} \mathrm{O}_{2}$ production. In addition, TRPM8 activation reduced the Ang II-induced upregulation of NADPH oxidase (NOX) 1 and NOX4 in VSMCs. Furthermore, TRPM8 activation relieved the Ang II-induced activation of ras homolog gene family, member A-rho associated protein kinase 2 and janus kinase 2 signaling pathways in VSMCs. In conclusion, the results presented in the current study indicated that TRPM8 downregulation by Ang II in VSMCs may be involved in hypertension.
\end{abstract}

Correspondence to: Dr Fu-Ming Shen or Dr Dong-Jie Li, Department of Pharmacy, Shanghai Tenth People's Hospital, Tongji University, 6 Building, 301 Yanchangzhong Road, Shanghai 200072, P.R. China

E-mail: fumingshen@tongji.edu.cn

E-mail: djli@tongji.edu.cn

Key words: transient receptor potential melastatin 8, hypertension, angiotensin II, vascular smooth muscle cells, reactive oxygen species

\section{Introduction}

Hypertension, a disorder associated with structural and functional vascular alterations, has been recognized as a major risk to cardiovascular health (1). As hypertension is correlated with coronary artery disease, left ventricular hypertrophy, congestive heart failure, obesity, hyperlipidemia, diabetes and cerebrovascular complications, it represents the biggest single contributor to the global burden of disease and to global mortality (1-4). Recent studies have demonstrated that some gene variants may be involved in hypertension $(2,3)$. Dysfunction of the renin-angiotensin-aldosterone system (RAAS), and over-activation of angiotensin II (Ang II), have been revealed as most important factors in the onset and progression of hypertension (5), cardiac remodeling (6), renal injury (7) and aortic aneurysm (8-11). Consequently, inhibiting the action of Ang II using angiotensin-converting enzyme inhibitors (ACEI) and Ang II type 1 receptor inhibitors have been widely accepted as a cornerstone in the treatment of hypertension $(12,13)$. Although the biological functions and molecular mechanisms of Ang II in cardiovascular system have not yet been not fully elucidated, the injury of vascular smooth muscle cells (VSMCs) induced by hypertension, as well as the accompanying high blood Ang II concentration, are considered to be primary causes for hypertension-associated vascular injury, including remodeling (14), thrombi transformation (15), neointimal hyperplasia (16) and calcification (17).

Transient receptor potential melastatin 8 (TRPM8) is a thermally-regulated $\mathrm{Ca}^{2+}$-permeable channel that is activated by cold sensations (18). As a universal cold receptor in the thermoregulation system, TRPM8 regulates body temperature $(18,19)$. Mice and rats experience a transient reduction in core body temperature following administration of TRPM8 antagonists (20). By contrast, activation of TRPM8 channels by selective agonists, such as menthol and icilin, demonstrates the opposite physiological hyperthermic effect by acting on peripheral neurons rather than the central nervous system $(21,22)$. In addition to this thermoregulatory effect, TRPM8 is involved in carcinogenesis (23), pain (24), inflammation (25), obesity (26), testosterone sensing (27) and eye-blinking regulation (28). Although previous studies have demonstrated that TRPM8 functions as a regulator of vascular tone that may be a promising therapeutic target for hypertension $(29,30)$, the role of TRPM8 in vascular biology is not completely understood. 
In the current study, it was hypothesized that TRPM8 serves an important role in VSMC biology under hypertensive conditions. Therefore, the expression of TRPM8 was investigated in the aorta media from rats subject to a two-kidney one-clip operation $(2 \mathrm{~K} 1 \mathrm{C})$, which is a widely-used renovascular hypertension model. In addition, the effect of benazepril, a commonly used ACEI, on the protein expression levels of TRPM8 was studied. Furthermore, the effects of exogenous Ang II treatment on TRPM8 expression in cultured VSMCs were explored. Furthermore, the potential influence of TRPM8 activation by a pharmacological agonist on oxidative stress, ras homolog gene family, member A (RhoA)-rho-associated protein kinase 2 (Rock2) signaling activation and janus kinase 2 (JAK2) signaling activation induced by Ang II treatment in VSMCs were investigated.

\section{Materials and methods}

Animals. A total of 24 male Sprague-Dawley rats (age, 8 weeks; weight, 220-260 g) were obtained from Sino-British SIPPR/BK Lab Animal Co., Ltd. (Shanghai, China) and housed under conditions involving a $12 \mathrm{~h} / 12 \mathrm{~h}$ light/dark cycle and a temperature of $23-25^{\circ} \mathrm{C}$ with free access to food and water. All animals used in this work received humane care in compliance with the institutional animal care guidelines and the Guide for Care and Use of Laboratory Animals published by the National Institutes of Health (Bethesda, MA, USA). The animal experiments were approved by the Animal Care and Use Committee of Tongji University (Shanghai, China).

2K1C hypertension model. The 2K1C hypertension model was performed as described previously (31). Rats were anesthetized with a combination of ketamine (40 mg/kg i.p.; Sigma-Aldrich; Merck Millipore, Darmstadt, Germany) /xylazine (13 mg/kg i.p.; Sigma-Aldrich; Merck Millipore), the right renal artery was isolated through a flank incision, and a silver clip $(0.2 \mathrm{~mm}$ internal gap) was placed on the renal artery. Sham-operated rats underwent the same surgical procedure except for the placement of the renal artery clip, and served as controls. The rats were returned to the cage after waking from the operation, and were maintained for 4 weeks. Blood pressure and heart rate (HR) measurements were recorded at 4 weeks post-2K1C surgery in conscious rats as described in a previous study by the authors (31). For ACEI benazepril treatment, benazepril (1.5 mg/kg/day; Beijing Novartis Pharma Co., Ltd., Beijing, China) was administrated via the chow for an additional 4 weeks in $2 \mathrm{~K} 1 \mathrm{C}$ rats.

Primary VSMC culture. Rat VSMCs were isolated using a standard enzymatic digestion technique as described previously $(32,33)$. Primary VSMCs were cultured in Dulbecco's modified Eagle's medium (DMEM; GE Healthcare Life Sciences, Logan, UT, USA) supplemented with $10 \%$ (v/v) fetal bovine serum (FBS; Gibco; Thermo Fisher Scientific, Inc., Waltham, MA, USA) in $95 \% \mathrm{O}_{2}$ and $5 \% \mathrm{CO}_{2}$. Experiments were performed using cells between passages 3 and 8 (34).

Cell study. The VSMCs $\left(1 \times 10^{6}\right)$ were seeded in wells of a 6-wells plate. Cells were grown to $60 \%$ confluence, and switched to serum-starved medium $(0.1 \%$ FBS $)$ for $12 \mathrm{~h}$ prior to further treatments to achieve synchronization. At the second day, the cells were switched to normal medium (DMEM + 10\% FBS) and treated with Ang II $\left(10^{-7} \mathrm{M}\right.$; Sigma-Aldrich; Merck Millipore) or menthol (100 mM; Sigma-Aldrich; Merck Millipore) for 5 days at $37^{\circ} \mathrm{C}$. Cells were then washed with PBS three times. Subsequently, cells were lysed with RIPA solution (Beyotime Institute of Biotechnology, Haimen, China) for determination of mRNA and protein levels. In some experiments, cells were induced by incubation of $\mathrm{H}_{2} \mathrm{O}_{2}(150 \mathrm{mM})$ for $12 \mathrm{~h}$ and then lysed for determination of the effect of ROS on TRPM8 expression.

Oxidative stress. The levels of reactive oxygen species (ROS) were measured using a flow cytometer (FACSCalibur; BD Biosciences, Franklin Lakes, NJ, USA) with a 2',7'-dichlorofluorescein-diacetate fluorescent assay (Invitrogen; Thermo Fisher Scientific, Inc.) according to the manufacturer's instructions and as described previously (35). The level of $\mathrm{H}_{2} \mathrm{O}_{2}$ was evaluated using the Hydrogen Peroxide assay kit (Abcam, Cambridge, MA,USA) according to the manufacturer's instructions and using the methods described previously (36). In the presence of horseradish peroxidase, the OxiRed Probe reacted with $\mathrm{H}_{2} \mathrm{O}_{2}$ to produce product with color $(\lambda \max =570 \mathrm{~nm})$ and red fluorescence (excitation/emission $=535 / 587 \mathrm{~nm}$ ).

Tissue sampling. At the end of 4-week treatment, rats were deeply anesthetized by chloral hydrate $(0.4 \mathrm{~g} / \mathrm{kg}$; Shanghai Meilian Biological Technology R\&D Co., Ltd., Shanghai, China) and then decapitated. The aortae were carefully harvested and washed by distilled water three times. Subsequently, the tissues were frozen and stored at $-80^{\circ} \mathrm{C}$.

Reverse transcription-quantitative polymerase chain reaction $(R T-q P C R)$. RT-qPCR was performed as described previously $(37,38)$. Total RNA was isolated from frozen tissues and the VSMCs cultured in 6-well dishes using RNAiso Plus reagent (Takara Bio, Inc., Otsu, Japan) and reverse transcribed with M-MLV (Promega Corporation, Madison, WI, USA) into cDNA using the methods described previously (39). The following primers were used for qPCR analysis: TRPM8, forward, 5'-GCTACGGACCAGCATTTCAT-3', and reverse, 5'-GCTTGTCAATGGGCTTCTT-3'; $\beta$-actin, forward, 5'-CCCATCTATGAGGGTTACGC-3', and reverse, 5'-TTT AATGTCACGCACGATTTC-3'. $\beta$-actin expression was used as an internal control. Quantification of mRNA was performed using the ABI Prism 7500 (Applied Biosystems; Thermo Fisher Scientific, Inc.) using a PrimeScript ${ }^{\mathrm{TM}}$ RT-PCR kit (Takara Bio, Inc.). The specificity of the RT-qPCR assay was assessed by melting point analysis and gel electrophoresis. The relative quantities of TRPM8 were calculated using the $2^{-\Delta \Delta \mathrm{Cq}}$ method with $\beta$-actin as an internal control $(40,41)$.

Western blotting. Western blotting analysis was performed as described previously $(42,43)$. Tissues and the VSMCs cultured in the 6-well dishes were homogenized in radioimmunoprecipitation lysis buffer containing $5 \%$ protease inhibitor cocktail (Pierce; Thermo Fisher Scientific, Inc.). Protein quantity was determined using a bicinchoninic acid protein assay kit (Beyotime Institute of Biotechnology) (44). Protein samples $(30-50 \mu \mathrm{g})$ were boiled for $15 \mathrm{~min}$ and run on $12 \%$ SDS-PAGE 

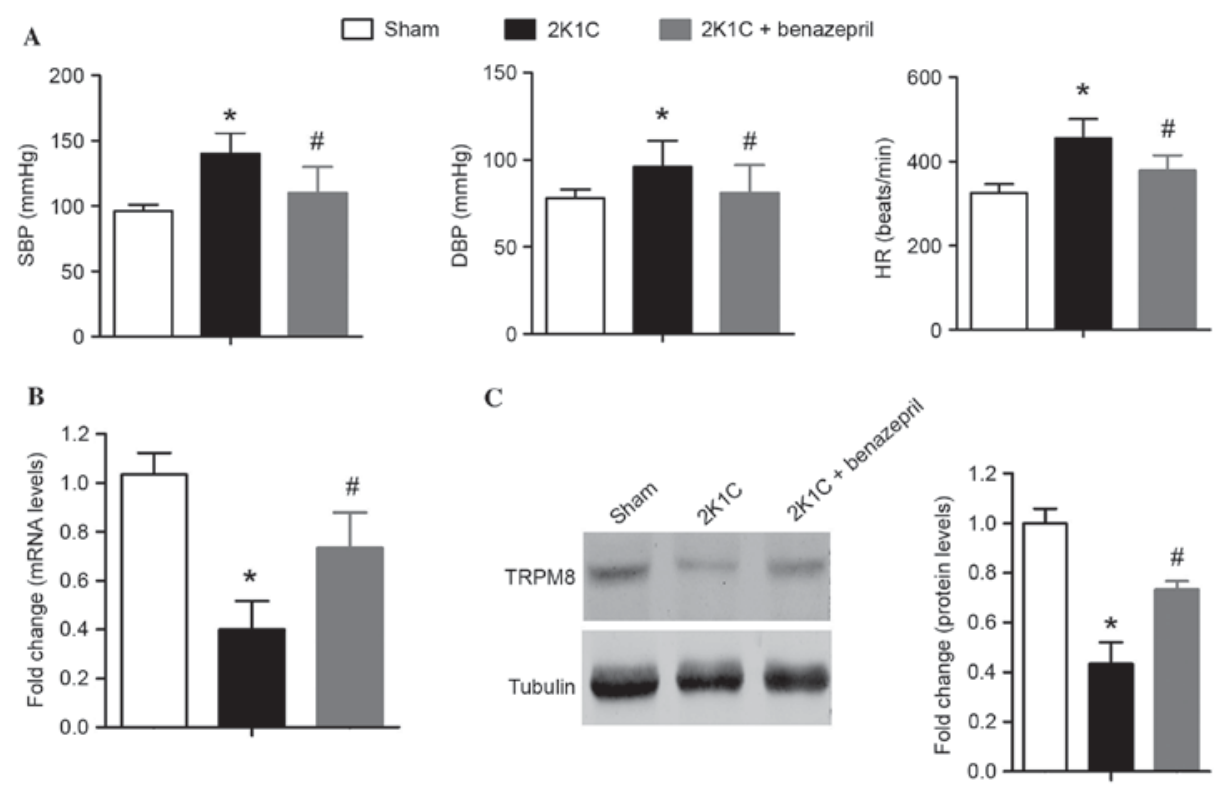

Figure 1. Altered expression of TRPM8 in the aorta media from hypertensive rats. (A) SBP, DBP and HR in Sham-operated, 2K1C and 2K1C+benazepril rats. These parameters were measured at 4 weeks following $2 \mathrm{~K} 1 \mathrm{C}$ operation. (B) The mRNA expression of TRPM8 in aorta from three groups of rats. (C) The protein expression of TRPM8 in aorta from three groups of rats using western blot analysis. Data are expressed as the mean \pm standard error $(\mathrm{n}=8)$. ${ }^{*} \mathrm{P}<0.05 \mathrm{vs}$. Sham; ${ }^{"} \mathrm{P}<0.05$ vs. 2K1C. TRPM8, transient receptor potential melastatin 8; SBP, systolic blood pressure; DBP, diastolic blood pressure; HR, heart rate; 2K1C, two-kidney one-clip operation.

gels, electroblotted onto nitrocellulose membranes, and immunoblotted at $4^{\circ} \mathrm{C}$ overnight with anti-TRPM8 (\#ab3243; dilution, 1:2,000; Abcam), anti-NADPH oxidase (NOX) 1 (\#ab55831; dilution, 1:2,000; Abcam), anti-NOX 4 (\#ab60940; dilution, 1:2,000; Abcam), anti-phosphorylated (p)-JAK2 (\#ab32101; dilution, 1:1,000; Abcam), anti-total (t)-JAK2 (\#ab39636; dilution, 1:1,000; Abcam), anti-RhoA (\#sc-32; dilution, 1:600; Santa Cruz Biotechnology, Inc., Dallas, TX, USA), anti-Rock2 (\#sc-1851; dilution, 1:800; Santa Cruz Biotechnology, Inc.) and anti-tubulin (\#sc-365791; dilution, 1:5,000; Santa Cruz Biotechnology, Inc.) followed by corresponding horseradish peroxidase-conjugated goat anti-mouse IgG (\#BA1050; Wuhan Boster Biological Technology, Ltd., Wuhan, China) and and goat anti-rabbit IgG (\#BA1054; Wuhan Boster Biological Technology, Ltd.) secondary antibodies (45). The signals were measured using the Amersham ECL Western Blotting assay kit (GE Healthcare Bio-Sciences, Pittsburgh, PA, USA) (46). Quantification of blots was conducted using the Quantity One software system, version 4.6.2 (Bio-Rad Laboratories, Inc., Hercules, CA, USA). Each experiment was repeated at least three times.

Statistical analysis. Data are represented as mean \pm standard error of the mean. Differences were evaluated by one-way analysis of variance followed by Tukey post hoc analysis. $\mathrm{P}<0.05$ was considered to indicate a statistically significant difference.

\section{Results}

Downregulation of TRPMS in the aorta media from hypertensive rats. The systolic blood pressure (SBP), diastolic blood pressure (DBP) and HR of 2K1C rats were significantly higher when compared with that of Sham-operated rats $(\mathrm{P}=0.0017$, $\mathrm{P}=0.0037$ and $\mathrm{P}=0.0055$, respectively; Fig. 1A). Benazepril treatment was associated with a significant reduction in the $2 \mathrm{~K} 1 \mathrm{C}$-induced increase in SBP, DBP and HR in $2 \mathrm{~K} 1 \mathrm{C}$ rats $(\mathrm{P}=0.0078, \mathrm{P}=0.0024$ and $\mathrm{P}=0.0015$, respectively; Fig. 1A). In the aortae of $2 \mathrm{~K} 1 \mathrm{C}$ hypertensive rats, the mRNA level of TRPM8 in de-nuded aortae (without endothelium and perivascular fat pad) was decreased by $\sim 60 \%$ compared with that in Sham-operated rats $(\mathrm{P}=0.0076$; Fig. 1B). However, benazepril treatment partially inhibited the downregulation of TRPM8 (Fig. 1B). Similar alterations were observed in TRPM8 protein expression levels (2K1C vs. Sham-operated, $\mathrm{P}=0.015$; Fig. 1C). These results suggest that TRPM8 is downregulated in the aortae of $2 \mathrm{~K} 1 \mathrm{C}$ hypertensive rats, which may be partially reversed by ACEI treatment. This suggests that TRPM8 downregulation in hypertension may be associated with the Ang II.

Ang II reduces TRPM8 expression in a dose- and time-dependent manner in VSMCs. To determine whether TRPM8 downregulation in hypertension is associated with Ang II, VSMCs were treated with recombinant Ang II. As expected, incubation of cells with $10^{-7} \mathrm{M}$ and $10^{-6} \mathrm{M}$ Ang II for 1 week induced a significant downregulation in TRPM8 mRNA $(\mathrm{P}=0.014$ and $\mathrm{P}=0.008$, respectively; Fig. $2 \mathrm{~A})$ and protein expression $(\mathrm{P}=0.021$ and $\mathrm{P}=0.015$, respectively; Fig. 2B). However, treatment of cells with a low concentration of Ang II $\left(10^{-8} \mathrm{M}\right)$ for 1 week was not associated with a significant reduction in TRPM8 mRNA and protein expression (Figs. 2A and B). The influence of incubation time on the Ang II-induced reduction in TRPM8 expression was then evaluated. Ang II $\left(10^{-7} \mathrm{M}\right)$ treatment did not modulate TRPM8 mRNA and protein expression at 3 days following treatment (Fig. 2C and D). However, the mRNA and protein levels of 


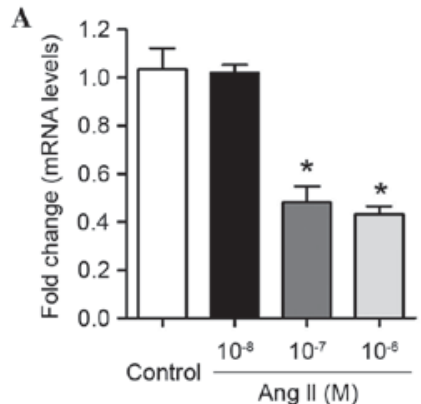

C

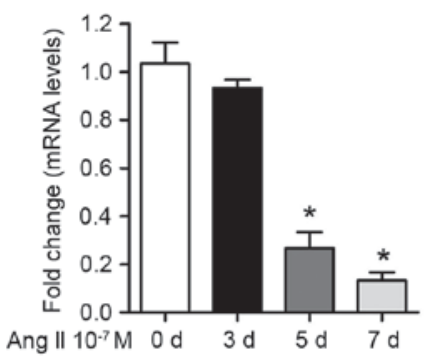

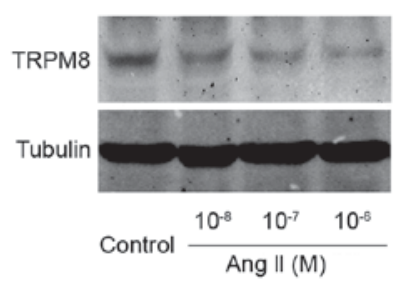

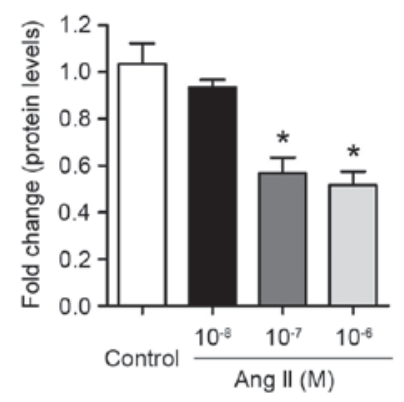

D

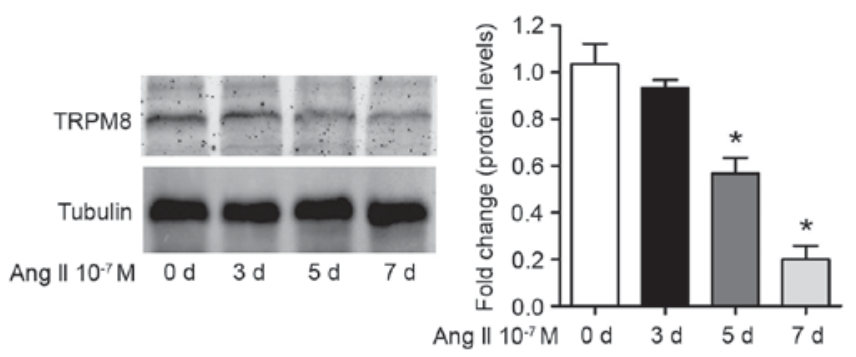

E

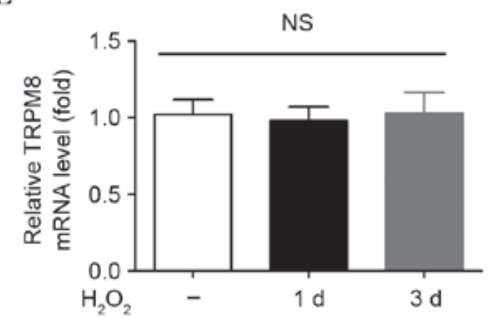

Figure 2. Ang II treatment reduces TRPM8 expression in cultured VSMCs. The effect of different concentrations of Ang II $\left(10^{-8}-10^{-6} \mathrm{M}\right)$ treatment on TRPM8 (A) mRNA and (B) protein expression levels in cultured rat VSMCs following 7 days ( $\left(\mathrm{P}<0.05\right.$ vs. Control). Effect of Ang II ( $\left.10^{-7} \mathrm{M}\right)$ treatment for 3,5 and 7 days on TRPM8 (C) mRNA and (D) protein expression levels in cultured rat VSMCs ( $\mathrm{P}<0.05$ vs. Control). (E) Effect of $\mathrm{H}_{2} \mathrm{O}_{2}$ incubation ( 30 mM) for 1 and 3 days on TRPM8 mRNA expression. Data are expressed as the mean \pm standard error $(n=8)$. TRPM8, transient receptor potential melastatin 8; VSMCs, vascular smooth muscle cells; Ang II, angiotensin II; NS, not significant.

TRPM8 at 7 days post-treatment were lower than those at 5 days post-treatment, which reached statistical significance when compared with day 0 (TRPM8 mRNA at day 5 vs. day 0 , $\mathrm{P}=0.019$; TRPM8 mRNA at day 7 vs. day $0, \mathrm{P}=0.003$; TRPM8 protein at day $5 \mathrm{vs}$. day $0, \mathrm{P}=0.014$; TRPM 8 protein at day 7 vs. day $0, \mathrm{P}=0.006$; Fig. $2 \mathrm{C}$ and $\mathrm{D})$. The data presented in the current study suggest that Ang II reduces TRPM8 expression in a dose- and time-dependent manner in VSMCs.

$\mathrm{H}_{2} \mathrm{O}_{2}$ was applied to VSMCs directly to increase ROS production, in order to determine whether ROS alters TRPM8 expression. TRPM8 mRNA expression was not altered by $\mathrm{H}_{2} \mathrm{O}_{2}$ treatment $(30 \mathrm{mM})$ for 1 day or 3 days in VSMCs (Fig. 2E). This suggests that the altered TRPM8 expression was not due to Ang II-induced ROS production.

TRPM8 activation attenuates Ang II-induced oxidative stress and upregulation of NOX enzymes in VSMCs. The effect of TRPM8 downregulation in Ang II-treated VSMCs was investigated. The induction of oxidative stress in VSMCs by Ang II is an important factor that is detrimental to vascular structure (1). Consistent with previous studies (47), significant enhancements of $\operatorname{ROS}(\mathrm{P}=0.00044$; Fig. $3 \mathrm{~A})$ and $\mathrm{H}_{2} \mathrm{O}_{2}$ $(\mathrm{P}=0.000016$; Fig. 3B) levels were detected in VSMCs treated with Ang II $\left(10^{-7} \mathrm{M}\right)$ for 5 days when compared with untreated controls. Interestingly, activation of TRPM8 by menthol, a selective TRPM8 agonist, significantly reduced the production of $\operatorname{ROS}(\mathrm{P}=0.0018$; Fig. $3 \mathrm{~A})$ and $\mathrm{H}_{2} \mathrm{O}_{2}(\mathrm{P}=0.0076$; Fig. $3 \mathrm{~B})$ when compared with Ang II-only treated cells, suggesting that activation of TRPM8 attenuates Ang II-induced oxidative stress in VSMCs. As NOX enzymes are major sources of ROS in the cardiovascular system (48), the expression of NOX1 and NOX4 was determined. Treatment of VSMCs with Ang II $\left(10^{-7} \mathrm{M}\right)$ for 5 days increased NOX1 and NOX4 protein expression by 2-3-fold in VSMCs (Fig. 3C). However, TRPM8 activation by menthol significantly attenuated the Ang II-induced upregulation of NOX1 and NOX4 $(\mathrm{P}=0.016$ and $\mathrm{P}=0.012$, respectively; Fig. 3C).

TRPM8 activation attenuates Ang II-induced activation of RhoA-Rock2 and JAK2 signaling pathways in VSMCs. Previous studies have demonstrated that the RhoA-Rock2 and JAK2 signaling pathway in VSMCs is involved in the pathogenesis of Ang II-dependent hypertension due to the increased presence of ROS $(49,50)$. Therefore, the present study investigated whether TRPM8 activation may affect RhoA-Rock2 and JAK 2 activation by Ang II in VSMCs. Consistent with the 
A

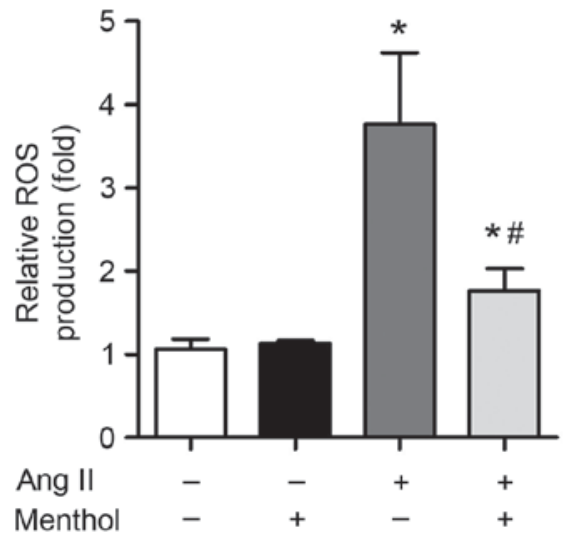

B

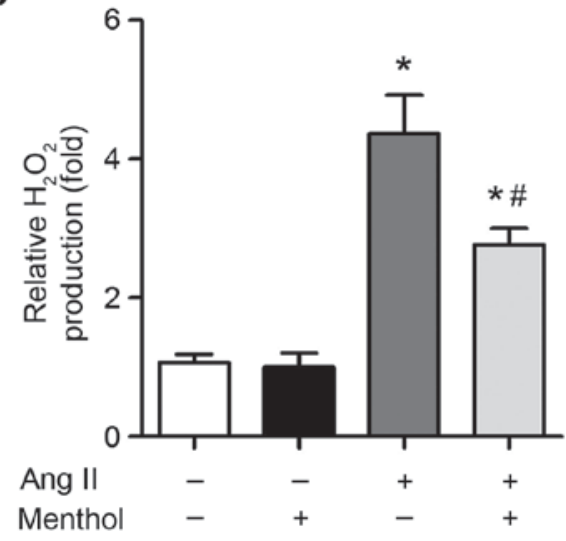

C

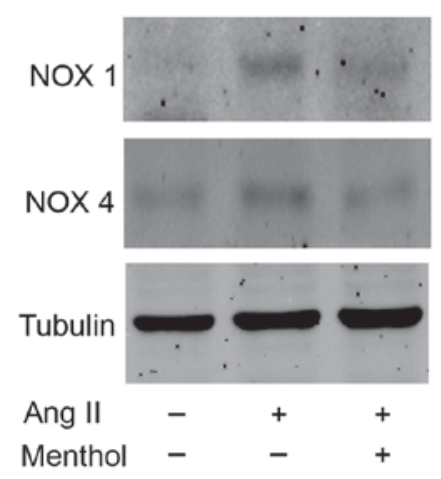

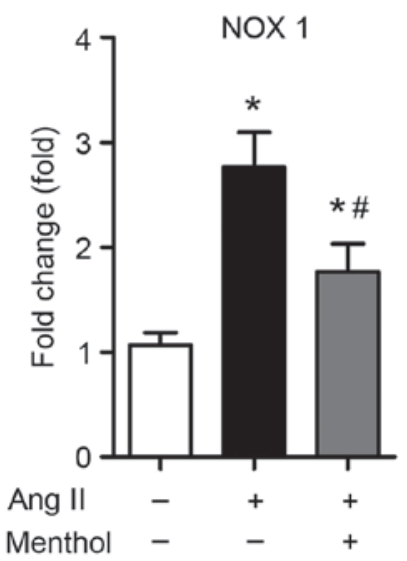

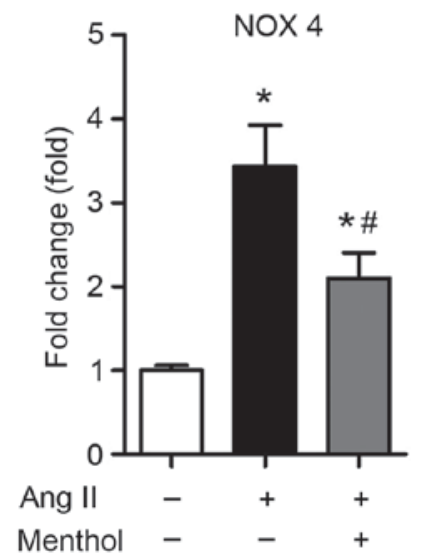

Figure 3. Activation of TRPM8 attenuated Ang II-induced oxidative stress and upregulated NOX1 and NOX4 expression in VSMCs. Effect of TRPM8 activation with the selective TRPM8 agonist, menthol, on Ang II-induced (A) ROS and (B) $\mathrm{H}_{2} \mathrm{O}_{2}$ production in cultured rat VSMCs. (C) Representative western blotting images and quantitative analysis of NOX1 and NOX4 protein levels in cultured rat VSMCs. Data are presented as the mean \pm standard error ( $\mathrm{n}=8$ ). ${ }^{*} \mathrm{P}<0.05$ vs. untreated controls; ${ }^{\mathrm{P}}<0.05$ vs. Ang II-only treated VSMCs. TRPM8, transient receptor potential melastatin 8; Ang II, angiotensin II; NOX, NAPDH oxidase; VSMCs, vascular smooth muscle cells; ROS, reactive oxygen species.

results of previous studies $(49,50)$, Ang II treatment $\left(10^{-7} \mathrm{M}\right)$ for 5 days activated RhoA-Rock2 (Fig. 4A) and induced JAK2 phosphorylation (Fig. 4B) in VSMCs. By contrast, TRPM8 activation by menthol partially inhibited Ang II-induced activation of RhoA-Rock2 (Fig. 4A) and JAK2 (Fig. 4B) signaling pathways in VSMCs.

\section{Discussion}

The superfamily of TRP channels is composed of proteins that were initially identified in the Drosophila eye (29). The first mammalian family of TRP channels identified was the transient receptor potential cation channels (51). In the following years, additional TRP families, such as TRPM (melastatin), TRPML (mucolipidins), TRPV (vanilloid receptor), TRPP (for polycystic kidney disease proteins) and TRPA (for ankyrin-rich proteins) were described (51). The TRPM family consists of 8 members that are subdivided into the following 4 groups based on their sequence homology: TRPM1 and TRPM3; TRPM4 and TRPM5; TRPM6 and TRPM7; and TRPM2 and TRPM8 (29). They regulate a number of cellular functions in normal and pathophysiological conditions (29). Among these members, TRPM7 has been most intensively studied for its role in the cardiovascular system. Touyz et al (52) reported that TRPM7 expression was lower in the VSMCs of spontaneously hypertensive rats in a genetic hypertensive model. Bradykinin, a potent vasodilator that lowers blood pressure, upregulated TRPM7 and its downstream target annexin-1 in VSMCs through phospholipase $\mathrm{C}$-dependent, protein kinase $\mathrm{C}$-dependent, c-Src-dependent and cAMP-independent pathways $(53,54)$. Ang II increased TRPM7 expression in VSMCs and TRPM7 was a functionally important regulator of $\mathrm{Mg}^{2+}$ homeostasis in VSMCs (55). In addition, magnesium negatively regulates vascular calcification and osteogenic differentiation through increased TRPM7 activity (56). Furthermore, upregulation of TRPM7 channels by Ang II contributes to the development of the proliferative phenotype of ascending aortic VSMCs (57). However, the possible roles of additional TRPM proteins in the biological functions of VSMCs have been rarely studied.

Recently, it has been reported that TRPM8 has regulatory function in the cardiovascular system, particularly in blood vessels (57). TRPM8 is expressed in pulmonary arterial and aortic smooth muscle (58). Notably, TRPM8 in smooth muscle was demonstrated to not be involved in cold-induced contraction, as it does in the nervous system. TRPM8 

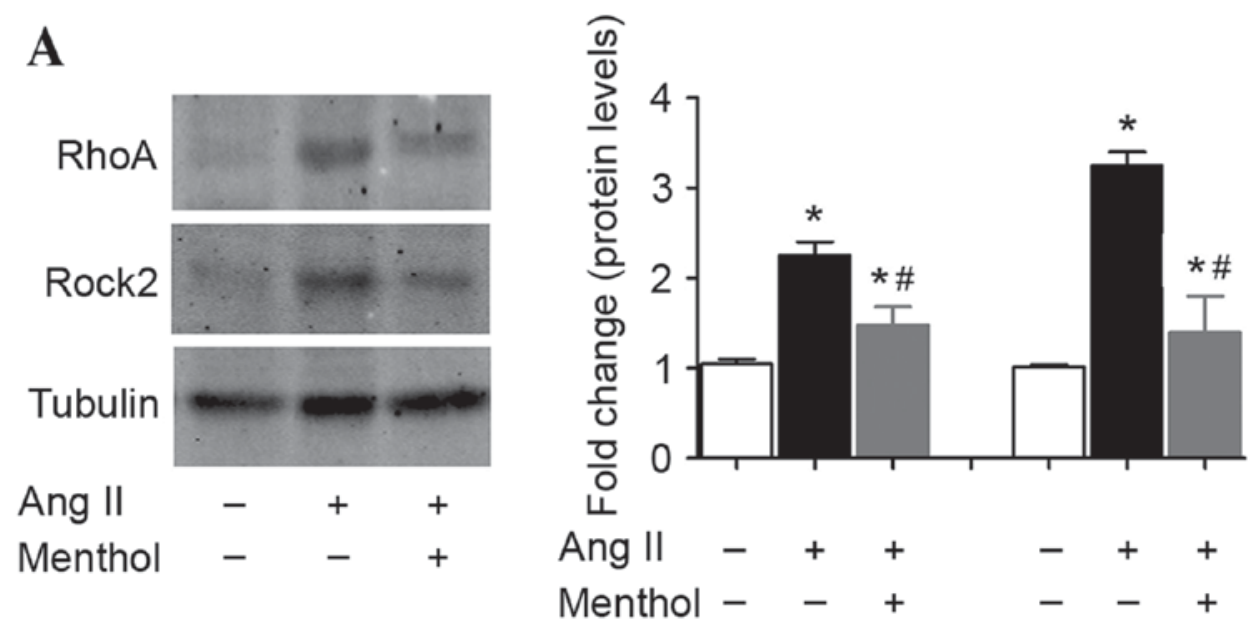

B
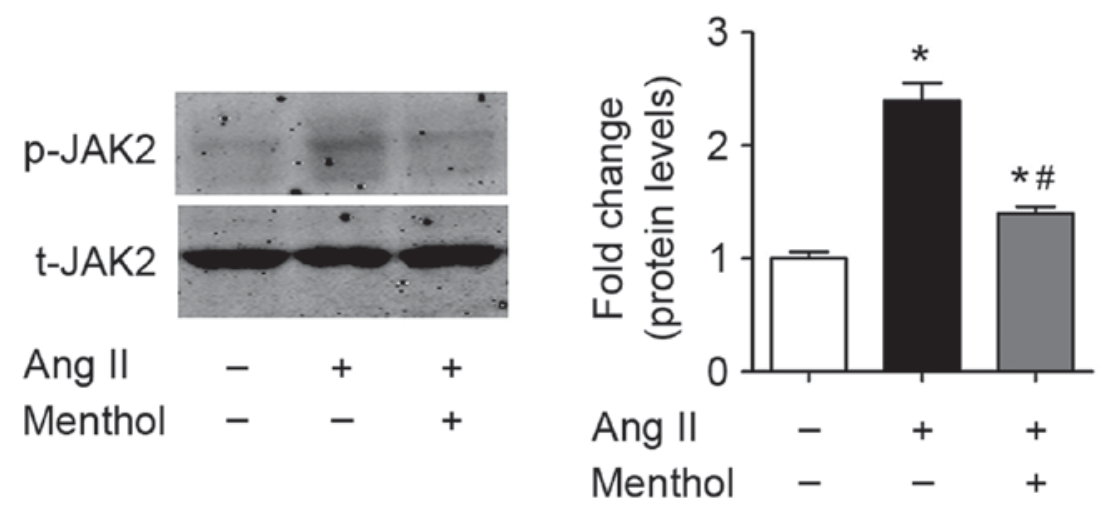

Figure 4. Activation of TRPM8 attenuated Ang II-induced activation of RhoA-Rock2 and JAK2 signaling pathways in VSMCs. (A) Representative western blotting images and quantitative analysis of the effect of TRPM8 activation on Ang II-induced activation of the RhoA-Rock2 pathway in cultured rat VSMCs. (B) Representative western blotting images and quantitative analysis of the effect of TRPM8 activation on Ang II-induced phosphorylation of JAK2 in cultured rat VSMCs. Data are presented as the mean \pm standard error $(n=8) . ~{ }^{*} \mathrm{P}<0.05$ vs. untreated controls; ${ }^{*} \mathrm{P}<0.05$ vs. Ang II-only treated VSMCs. TRPM8, transient receptor potential melastatin 8; Ang II, angiotensin II; RhoA, ras homolog gene family, member A; Rock2, rho-associated protein kinase 2; p-JAK2, phosphorylated janus kinase 2; t-JAK2, total janus kinase 2; VSMCs, vascular smooth muscle cells.

activation led to relaxation of vessels (29). In addition, TRPM8 activation by chronic dietary menthol attenuated mesenteric arterial constriction and lowered blood pressure in a genetic model of rat hypertension via inhibition of RhoA-Rho kinase expression and activity in an in vivo study (30). The RhoA-Rho kinase cascade serves key roles in pressure overload-induced right ventricular hypertrophy and dysfunction (59) and neointima formation (60). In addition, there is crucial Rho-kinase inhibition during cardiac development in the pathogenesis of hypertension $(61,62)$. These results suggest that TRPM8 is involved in the regulation of vascular tone. However, the precise role of TRPM8 in hypertension and hypertension-associated pathophysiology is not completely known. To the best of our knowledge, the results of the present study are the first to demonstrate that TRPM8 is downregulated in $2 \mathrm{~K} 1 \mathrm{C}$ rat aortae. The results are consistent with a recent report by Liu et al (63), which demonstrated a significant decrease in TRPM8 mRNA and protein expression in the pulmonary arteries of pulmonary hypertensive rats. In the present study, when the hypertension in $2 \mathrm{~K} 1 \mathrm{C}$ rats was partially reversed by ACEI treatment, the upregulation of TRPM8 was also partially reversed, suggesting the TRPM8 downregulation may be a direct consequence of hypertension or hypertension-associated factors. In the following experiments, TRPM8 was observed to be downregulated in Ang II-treated VSMCs, which supports the hypothesis that the high blood Ang II concentration may be the cause of TRPM8 downregulation during hypertension.

$2 \mathrm{~K} 1 \mathrm{C}$ is a well-established hypertension animal model. This model has been used for several decades (64-68), and the authors of the present study have used this model in a previous study (69). In this model, not only is the blood level of Ang II increased, the local tissue levels of Ang II are also enhanced. The enhanced Ang II concentrations in the aorta, kidney and brain significantly contribute to the pathogenesis of hypertension $(65,68)$. Benazepril, also known as Lotensin, is an ACEI that was approved by the US Food and Drug Administration in 1991. There are numerous pharmacodynamic data regarding benazepril (70-72). According to an extensive review regarding the pharmacodynamic and pharmacokinetic properties of benazepril (73), benazepril remarkably suppresses human plasma and tissue Ang II levels via inhibiting ACE activity by $\sim 80-90 \%$ both in vitro and in vivo. Mochel et al (74) recently provided a comprehensive description of the effect of benazepril on the dynamics of the RAAS in dogs. It was demonstrated that the plasma 
Ang II concentration decreased markedly following a bolus administration of benazepril. Consequently, existing data regarding the inhibitory effects of benazepril on plasma and tissue Ang II levels have been considered in the present study. The in vitro experiments demonstrated that Ang II treatment reduced TRPM8 expression in cultured VSMCs, while activation of TRPM8 reversed Ang II-induced oxidative stress and upregulated NOX enzymes in VSMCs. These results suggest that Ang II may directly regulate TRPM8.

Of particular note, the results of the present study indicated that activation of TRPM8, using a pharmacological agonist, partially reversed the Ang II-induced oxidative stress and JAK2 signaling activation. Oxidative stress serves an important role in the pathogenesis of hypertension $(75,76)$. Ang II-mediated oxidative stress and DNA damage accelerates cellular senescence in VSMCs (47). During this process, NOX1 and NOX4 are two major sources of ROS in Ang II-induced vascular hypertrophy (48). In addition, RhoA-Rock2 and JAK2 signaling pathways are involved in the pathogenesis of hypertension or vascular remodeling due to the increased presence of ROS $(41,49,77)$. In the present study, activation of TRPM8 significantly inhibited the increase in NOX1 and NOX4 in Ang II-treated VSMCs, and suppressed activation of the RhoA-Rock2 and JAK2 signaling pathways. Recently, Sun et al (30) demonstrated that chronic dietary menthol administration for 8 weeks prevented mesenteric arterial constriction and lowered blood pressure in genetic hypertensive rats with high Ang II levels. In addition, this study demonstrated that TRPM8 effects were associated with inhibition of intracellular calcium release from the sarcoplasmic reticulum and RhoA kinase activity in arteries (30). The results of the present study are consistent with this previous study. In addition, the role of TRPM8 in additional vascular cells, such as endothelial cells, may be of important interest. This question requires further investigation in the future.

The RAAS modulates cardiovascular functions, as well as a number of additional biological functions. As some thermoregulatory proteins and RNAs have been demonstrated to be involved in the development of brown and beige fat, which is closely associated with metabolism (78-82), the authors of the present study hypothesize that TRPM8 may be a crucial regulator of adiposity and metabolism. Notably, the RAAS serves an important role in metabolism via multiple molecular mechanisms $(83,84)$. Consequently, the association between the RAAS and TRPM8 may be more complex than assumed in the current study.

In conclusion, the results of the present study demonstrated that TRPM8 may be involved in the pathophysiology of hypertension, and support the notion that pharmacological activation of TRPM8 may be a novel approach for treatment of hypertension and other Ang II-induced vascular injuries, such as aneurysm.

\section{Acknowledgements}

The present study was supported by grants from the National Natural Foundation of China (grant nos. 81300081 and 81370558), the Shanghai Natural Science Foundation (grant no. 13ZR1459300) and the Fundamental Research Funds for the Central Universities-Multi-Subjects Crossing of Tongji University (grant no. 1501219097).

\section{References}

1. Poulter NR, Prabhakaran D and Caulfield M: Hypertension. Lancet 386: 801-812, 2015.

2. He D, Fu M, Miao S, Hotta K, Chandak GR and Xi B: FTO gene variant and risk of hypertension: A meta-analysis of 57,464 hypertensive cases and 41,256 controls. Metabolism 63: 633-639, 2014.

3. Wu YL, Hu CY, Lu SS, Gong FF, Feng F, Qian ZZ, Ding XX, Yang HY and Sun YH: Association between methylenetetrahydrofolate reductase (MTHFR) C677T/A1298C polymorphisms and essential hypertension: A systematic review and meta-analysis. Metabolism 63: 1503-1511, 2014.

4. Rocha NG, Templeton DL, Greiner JJ, Stauffer BL and DeSouza CA: Metabolic syndrome and endothelin-1 mediated vasoconstrictor tone in overweight/obese adults. Metabolism 63: 951-956, 2014

5. Ait Aissa K, Lagrange J, Mohamadi A, Louis H, Houppert B, Challande P, Wahl D, Lacolley P and Regnault V: Vascular smooth muscle cells are responsible for a prothrombotic phenotype of spontaneously hypertensive rat arteries. Arterioscler Thromb Vasc Biol 35: 930-937, 2015.

6. Zhang C, Li Y, Wang C, Wu Y, Cui W, Miwa T, Sato S, Li H, Song WC and Du J: Complement 5a receptor mediates angiotensin II-induced cardiac inflammation and remodeling. Arterioscler Thromb Vasc Biol 34: 1240-1248, 2014.

7. Xia Y, Jin X, Yan J, Entman ML and Wang Y: CXCR6 plays a critical role in angiotensin II-induced renal injury and fibrosis. Arterioscler Thromb Vasc Biol 34: 1422-1428, 2014.

8. Usui F, Shirasuna K, Kimura H, Tatsumi K, Kawashima A, Karasawa T, Yoshimura K, Aoki H, Tsutsui H, Noda T, et al: Inflammasome activation by mitochondrial oxidative stress in macrophages leads to the development of angiotensin II-induced aortic aneurysm. Arterioscler Thromb Vasc Biol 35: 127-136, 2015.

9. Kigawa Y, Miyazaki T, Lei XF, Nakamachi T, Oguchi T, Kim-Kaneyama JR, Taniyama M, Tsunawaki S, Shioda S and Miyazaki A: NADPH oxidase deficiency exacerbates angiotensin II-induced abdominal aortic aneurysms in mice. Arterioscler Thromb Vasc Biol 34: 2413-2420, 2014.

10. Krishna SM, Seto SW, Jose RJ, Biros E, Moran CS, Wang Y, Clancy $\mathrm{P}$ and Golledge $\mathrm{J}$ : A peptide antagonist of thrombospondin-1 promotes abdominal aortic aneurysm progression in the angiotensin II-infused apolipoprotein-E-deficient mouse. Arterioscler Thromb Vasc Biol 35: 389-398, 2015.

11. Davis FM, Rateri DL, Balakrishnan A, Howatt DA, Strickland DK, Muratoglu SC, Haggerty CM, Fornwalt BK, Cassis LA and Daugherty A: Smooth muscle cell deletion of low-density lipoprotein receptor-related protein 1 augments angiotensin II-induced superior mesenteric arterial and ascending aortic aneurysms. Arterioscler Thromb Vasc Biol 35: $155-162,2015$.

12. Zreikat HH, Harpe SE, Slattum PW, Mays DP, Essah PA and Cheang KI: Effect of Renin-Angiotensin system inhibition on cardiovascular events in older hypertensive patients with metabolic syndrome. Metabolism 63: 392-399, 2014.

13. Kristensen KE, Torp-Pedersen C, Gislason GH, Egfjord M, Rasmussen HB and Hansen PR: Angiotensin-converting enzyme inhibitors and angiotensin II receptor blockers in patients with abdominal aortic aneurysms: Nation-wide cohort study. Arterioscler Thromb Vasc Biol 35: 733-740, 2015.

14. Pruthi D, McCurley A, Aronovitz M, Galayda C, Karumanchi SA and Jaffe IZ: Aldosterone promotes vascular remodeling by direct effects on smooth muscle cell mineralocorticoid receptors. Arterioscler Thromb Vasc Biol 34: 355-364, 2014.

15. Alias S, Redwan B, Panzenböck A, Winter MP, Schubert U, Voswinckel R, Frey MK, Jakowitsch J, Alimohammadi A, Hobohm L, et al: Defective angiogenesis delays thrombus resolution: A potential pathogenetic mechanism underlying chronic thromboembolic pulmonary hypertension. Arterioscler Thromb Vasc Biol 34: 810-819, 2014.

16. Manka D, Chatterjee TK, Stoll LL, Basford JE, Konaniah ES, Srinivasan R, Bogdanov VY, Tang Y, Blomkalns AL, Hui DY and Weintraub NL: Transplanted perivascular adipose tissue accelerates injury-induced neointimal hyperplasia: Role of monocyte chemoattractant protein-1. Arterioscler Thromb Vasc Biol 34: 1723-1730, 2014.

17. Demer LL and Tintut Y: Inflammatory, metabolic, and genetic mechanisms of vascular calcification. Arterioscler Thromb Vasc Biol 34: 715-723, 2014. 
18. Peier AM, Moqrich A, Hergarden AC, Reeve AJ, Andersson DA, Story GM, Earley TJ, Dragoni I, McIntyre P, Bevan S and Patapoutian A: A TRP channel that senses cold stimuli and menthol. Cell 108: 705-715, 2002.

19. McKemy DD, Neuhausser WM and Julius D: Identification of a cold receptor reveals a general role for TRP channels in thermosensation. Nature 416: 52-58, 2002.

20. Almeida MC, Hew-Butler T, Soriano RN, Rao S, Wang W, Wang J, Tamayo N, Oliveira DL, Nucci TB, Aryal P, et al: Pharmacological blockade of the cold receptor TRPM8 attenuates autonomic and behavioral cold defenses and decreases deep body temperature. J Neurosci 32: 2086-2099, 2012.

21. Knowlton WM, Daniels RL, Palkar R, McCoy DD and McKemy DD: Pharmacological blockade of TRPM8 ion channels alters cold and cold pain responses in mice. PLoS One 6: e25894, 2011

22. Morenilla-Palao C, Luis E, Fernández-Peña C, Quintero E, Weaver JL, Bayliss DA and Viana F: Ion channel profile of TRPM8 cold receptors reveals a role of TASK-3 potassium channels in thermosensation. Cell Rep 8: 1571-1582, 2014.

23. Borrelli F, Pagano E, Romano B, Panzera S, Maiello F, Coppola D, De Petrocellis L, Buono L, Orlando P and Izzo AA: Colon carcinogenesis is inhibited by the TRPM8 antagonist cannabigerol, a Cannabis-derived non-psychotropic cannabinoid. Carcinogenesis 35: 2787-2797, 2014.

24. Patel R, Gonçalves L, Leveridge M, Mack SR, Hendrick A, Brice NL and Dickenson AH: Anti-hyperalgesic effects of a novel TRPM8 agonist in neuropathic rats: A comparison with topical menthol. Pain 155: 2097-2107, 2014

25. Ramachandran R, Hyun E, Zhao L, Lapointe TK, Chapman K, Hirota CL, Ghosh S, McKemy DD, Vergnolle N, Beck PL, et al: TRPM8 activation attenuates inflammatory responses in mouse models of colitis. Proc Natl Acad Sci USA 110: 7476-7481, 2013.

26. Ma S, Yu H, Zhao Z, Luo Z, Chen J, Ni Y, Jin R, Ma L, Wang P, Zhu Z, et al: Activation of the cold-sensing TRPM8 channel triggers UCP1-dependent thermogenesis and prevents obesity. J Mol Cell Biol 4: 88-96, 2012.

27. Asuthkar S, Elustondo PA, Demirkhanyan L, Sun X, Baskaran P, Velpula KK, Thyagarajan B, Pavlov EV and Zakharian E: The TRPM8 protein is a testosterone receptor: I. Biochemical evidence for direct TRPM8-testosterone interactions. J Biol Chem 290: 2659-2669, 2015.

28. Quallo T, Vastani N, Horridge E, Gentry C, Parra A, Moss S, Viana F, Belmonte C, Andersson DA and Bevan S: TRPM8 is a neuronal osmosensor that regulates eye blinking in mice. Nat Commun 6: 7150, 2015.

29. Johnson CD, Melanaphy D, Purse A, Stokesberry SA, Dickson $P$ and Zholos AV: Transient receptor potential melastatin 8 channel involvement in the regulation of vascular tone. Am J Physiol Heart Circ Physiol 296: H1868-H1877, 2009.

30. Sun J, Yang T, Wang P, Ma S, Zhu Z, Pu Y, Li L, Zhao Y, Xiong S, Liu D and Zhu Z: Activation of cold-sensing transient receptor potential melastatin subtype 8 antagonizes vasoconstriction and hypertension through attenuating RhoA/Rho kinase pathway. Hypertension 63: 1354-1363, 2014

31. Chen JK,ZhaoT,Ni M,LiDJ,TaoX and Shen FM: Downregulation of alpha7 nicotinic acetylcholine receptor in two-kidney one-clip hypertensive rats. BMC Cardiovasc Disord 12: 38, 2012.

32. Kato Y, Yokoyama U, Yanai C, Ishige R, Kurotaki D, Umemura M, Fujita T, Kubota T, Okumura S, Sata M, et al: Epac1 deficiency attenuated vascular smooth muscle cell migration and neointimal formation. Arterioscler Thromb Vasc Biol 35: 2617-2625, 2015.

33. Weise-Cross L, Taylor JM and Mack CP: Inhibition of diaphanous formin signaling in vivo impairs cardiovascular development and alters smooth muscle cell phenotype. Arterioscler Thromb Vasc Biol 35: 2374-2383, 2015

34. Fernandez I, Martin-Garrido A, Zhou DW, Clempus RE, Seidel-Rogol B, Valdivia A, Lassègue B, García AJ, Griendling KK and San Martin A: Hic-5 mediates TGF $\beta$-induced adhesion in vascular smooth muscle cells by a Nox4-dependent mechanism. Arterioscler Thromb Vasc Biol 35: 1198-1206, 2015.

35. Song J, Li J, Hou F, Wang X and Liu B: Mangiferin inhibits endoplasmic reticulum stress-associated thioredoxin-interacting protein/NLRP3 inflammasome activation with regulation of AMPK in endothelial cells. Metabolism 64: 428-437, 2015.

36. Omodei D, Pucino V, Labruna G, Procaccini C, Galgani M, Perna F, Pirozzi D, De Caprio C, Marone G, Fontana L, et al Immune-metabolic profiling of anorexic patients reveals an anti-oxidant and anti-inflammatory phenotype. Metabolism 64: $396-405,2015$
37. Hwang HJ, Jung TW, Hong HC, Seo JA, Kim SG, Kim NH, Choi KM, Choi DS, Baik SH and Yoo HJ: LECT2 induces atherosclerotic inflammatory reaction via CD209 receptor-mediated JNK phosphorylation in human endothelial cells. Metabolism 64: 1175-1182, 2015

38. Kurano M, Hara M, Satoh H and Tsukamoto K: Hepatic NPC1L1 overexpression ameliorates glucose metabolism in diabetic mice via suppression of gluconeogenesis. Metabolism 64: 588-596, 2015.

39. Zhou XB, Feng YX, Sun Q, Lukowski R, Qiu Y, Spiger K, Li Z, Ruth P, Korth M, Skolnik EY, et al: Nucleoside diphosphate kinase B-activated intermediate conductance potassium channels are critical for neointima formation in mouse carotid arteries. Arterioscler Thromb Vasc Biol 35: 1852-1861, 2015.

40. Livak KJ and Schmittgen TD: Analysis of relative gene expression data using real-time quantitative PCR and the 2(-Delta Delta C(T)) Method. Methods 25: 402-408, 2001.

41. Lee MJ, Kim EH, Lee SA, Kang YM, Jung CH, Yoon HK, Seol SM, Lee YL, Lee WJ and Park JY: Dehydroepiandrosterone prevents linoleic acid-induced endothelial cell senescence by increasing autophagy. Metabolism 64: 1134-1145, 2015.

42. Ray Hamidie RD, Yamada T, Ishizawa R, Saito Y and Masuda K: Curcumin treatment enhances the effect of exercise on mitochondrial biogenesis in skeletal muscle by increasing cAMP levels. Metabolism 64: 1334-1347, 2015.

43. Kadota Y, Toyoda T, Hayashi-Kato M, Kitaura Y and Shimomura Y: Octanoic acid promotes branched-chain amino acid catabolisms via the inhibition of hepatic branched-chain alpha-keto acid dehydrogenase kinase in rats. Metabolism 64: $1157-1164,2015$

44. Fu L, Bruckbauer A, Li F, Cao Q, Cui X, Wu R, Shi H, Zemel MB and Xue B: Leucine amplifies the effects of metformin on insulin sensitivity and glycemic control in diet-induced obese mice. Metabolism 64: 845-856, 2015.

45. Soe NN, Sowden M, Baskaran P, Smolock EM, Kim Y, Nigro P and Berk BC: Cyclophilin A is required for angiotensin II-induced p47phox translocation to caveolae in vascular smooth muscle cells. Arterioscler Thromb Vasc Biol 33: 2147-2153, 2013.

46. Wu YJ, Guo X, Li CJ, Li DQ, Zhang J, Yang Y, Kong Y, Guo H, Liu DM and Chen LM: Dipeptidyl peptidase-4 inhibitor, vildagliptin, inhibits pancreatic beta cell apoptosis in association with its effects suppressing endoplasmic reticulum stress in $\mathrm{db} / \mathrm{db}$ mice. Metabolism 64: 226-235, 2015.

47. Seshiah PN, Weber DS, Rocic P, Valppu L, Taniyama Y and Griendling KK: Angiotensin II stimulation of NAD (P)H oxidase activity: Upstream mediators. Circ Res 91: 406-413, 2002.

48. Lasségue B, San Martín A and Griendling KK: Biochemistry, physiology, and pathophysiology of NADPH oxidases in the cardiovascular system. Circ Res 110: 1364-1390, 2012.

49. Kirabo A, Kearns PN, Jarajapu YP, Sasser JM, Oh SP, Grant MB Kasahara H, Cardounel AJ, Baylis C, Wagner KU and Sayeski PP: Vascular smooth muscle Jak2 mediates angiotensin II-induced hypertension via increased levels of reactive oxygen species. Cardiovasc Res 91: 171-179, 2011.

50. Montezano AC, Callera GE, Yogi A, He Y, Tostes RC, He G, Schiffrin EL and Touyz RM: Aldosterone and angiotensin II synergistically stimulate migration in vascular smooth muscle cells through c-Src-regulated redox-sensitive RhoA pathways. Arterioscler Thromb Vasc Biol 28: 1511-1518, 2008.

51. Clapham DE, Runnels LW and Strübing C: The trp ion channel family. Nat Rev Neurosci 2: 387-396, 2001.

52. Touyz RM, He Y, Montezano AC, Yao G, Chubanov V, Gudermann $\mathrm{T}$ and Callera GE: Differential regulation of transient receptor potential melastatin 6 and 7 cation channels by Ang II in vascular smooth muscle cells from spontaneously hypertensive rats. Am J Physiol Regul Integr Comp Physiol 290: R73-R78, 2006.

53. Yogi A, Callera GE, Tostes R and Touyz RM: Bradykinin regulates calpain and proinflammatory signaling through TRPM7-sensitive pathways in vascular smooth muscle cells. Am J Physiol Regul Integr Comp Physiol 296: R201-R207, 2009.

54. Callera GE, He Y, Yogi A, Montezano AC, Paravicini T, Yao G and Touyz RM: Regulation of the novel Mg2+ transporter transient receptor potential melastatin 7 (TRPM7) cation channel by bradykinin in vascular smooth muscle cells. J Hypertens 27: 155-166, 2009.

55. He Y, Yao G, Savoia C and Touyz RM: Transient receptor potential melastatin 7 ion channels regulate magnesium homeostasis in vascular smooth muscle cells: Role of angiotensin II. Circ Res 96: 207-215, 2005. 
56. Montezano AC,Zimmerman D, Yusuf H, BurgerD, Chignalia AZ Wadhera V, van Leeuwen FN and Touyz RM: Vascular smooth muscle cell differentiation to an osteogenic phenotype involves TRPM7 modulation by magnesium. Hypertension 56: 453-462, 2010.

57. Zhang Z, Wang M, Fan XH, Chen JH, Guan YY and Tang YB: Upregulation of TRPM7 channels by angiotensin II triggers phenotypic switching of vascular smooth muscle cells of ascending aorta. Circ Res 111: 1137-1146, 2012.

58. Yang XR, Lin MJ, McIntosh LS and Sham JS: Functional expression of transient receptor potential melastatin- and vanilloid-related channels in pulmonary arterial and aortic smooth muscle. Am J Physiol Lung Cell Mol Physiol 290: L1267-L1276, 2006.

59. Ikeda S, Satoh K, Kikuchi N, Miyata S, Suzuki K, Omura J, Shimizu T, Kobayashi K, Kobayashi K, Fukumoto Y, et al: Crucial role of rho-kinase in pressure overload-induced right ventricular hypertrophy and dysfunction in mice. Arterioscler Thromb Vasc Biol 34: 1260-1271, 2014.

60. Gadang V, Konaniah E, Hui DY and Jaeschke A: Mixed-lineage kinase 3 deficiency promotes neointima formation through increased activation of the RhoA pathway in vascular smooth muscle cells. Arterioscler Thromb Vasc Biol 34: 1429-1436, 2014.

61. Ellawindy A, Satoh K, Sunamura S, Kikuchi N, Suzuki K, Minami T, Ikeda S, Tanaka S, Shimizu T, Enkhjargal B, et al Rho-Kinase inhibition during early cardiac development causes arrhythmogenic right ventricular cardiomyopathy in mice. Arterioscler Thromb Vasc Biol 35: 2172-2184, 2015.

62. Shimokawa H and Satoh K: 2015 ATVB Plenary Lecture: Translational research on rho-kinase in cardiovascular medicine. Arterioscler Thromb Vasc Biol 35: 1756-1769, 2015.

63. Liu XR, Liu Q, Chen GY, Hu Y, Sham JS and Lin MJ: Down-regulation of TRPM8 in pulmonary arteries of pulmonary hypertensive rats. Cell Physiol Biochem 31: 892-904, 2013.

64. Greenberg S: Vascular responses of the perfused intestine to vasoactive agents during the development of two-kidney, one-clip Goldblatt hypertension in dogs. Circ Res 48: 895-906, 1981.

65. Morishita R, Higaki J, Miyazaki M and Ogihara T: Possible role of the vascular renin-angiotensin system in hypertension and vascular hypertrophy. Hypertension 19 (Suppl 2): II62-II67, 1992

66. Cervenka L, Horácek V, Vanecková I, Hubácek JA, Oliverio MI, Coffman TM and Navar LG: Essential role of AT1A receptor in the development of $2 \mathrm{~K} 1 \mathrm{C}$ hypertension. Hypertension 40 : 735-741, 2002.

67. Xie QY, Sun M, Yang TL and Sun ZL: Losartan reduces monocyte chemoattractant protein-1 expression in aortic tissues of 2K1C hypertensive rats. Int J Cardiol 110: 60-66, 2006.

68. Maxwell MH, Lupu AN, Viskoper RJ, Aravena LA and Waks UA: Mechanisms of hypertension during the acute and intermediate phases of the one-clip, two-kidney model in the dog. Circ Res 40 (5 Suppl 1): I24-I28, 1977.

69. Li DJ, Evans RG, Yang ZW, Song SW, Wang P, Ma XJ, Liu C, $\mathrm{Xi}$ T, Su DF and Shen FM: Dysfunction of the cholinergic anti-inflammatory pathway mediates organ damage in hypertension. Hypertension 57: 298-307, 2011.

70. Jamerson K, Weber MA, Bakris GL, Dahlöf B, Pitt B, Shi V, Hester A, Gupte J, Gatlin M and Velazquez EJ; ACCOMPLISH Trial Investigators: Benazepril plus amlodipine or hydrochlorothiazide for hypertension in high-risk patients. N Engl J Med 359: 2417-2428, 2008.
71. Jamerson KA, Devereux R, Bakris GL, Dahlöf B, Pitt B, Velazquez EJ, Weir M, Kelly RY, Hua TA, Hester A and Weber MA: Efficacy and duration of benazepril plus amlodipine or hydrochlorothiazide on 24-h ambulatory systolic blood pressure control. Hypertension 57: 174-179, 2011.

72. Valvo E, Casagrande P, Bedogna V, Antiga L, Alberti D, Zamboni M, Perobelli L, Dal Santo F and Maschio G: Systemic and renal effects of a new angiotensin converting enzyme inhibitor, benazepril, in essential hypertension. J Hypertens 8: 991-995, 1990

73. Balfour JA and Goa KL: Benazepril. A review of its pharmacodynamic and pharmacokinetic properties, and therapeutic efficacy in hypertension and congestive heart failure. Drugs 42: 511-539, 1991.

74. Mochel JP, Fink M, Peyrou M, Soubret A, Giraudel JM and Danhof M: Pharmacokinetic/pharmacodynamic modeling of renin-angiotensin aldosterone biomarkers following angiotensin-converting enzyme (ACE) inhibition therapy with benazepril in dogs. Pharm Res 32: 1931-1946, 2015.

75. Dikalov SI, Nazarewicz RR, Bikineyeva A, Hilenski L, Lassègue B, Griendling KK, Harrison DG and Dikalova AE: Nox2-induced production of mitochondrial superoxide in angiotensin II-mediated endothelial oxidative stress and hypertension. Antioxid Redox Signal 20: 281-294, 2014

76. Lu S, Xiang L, Clemmer JS, Mittwede PN and Hester RL: Oxidative stress increases pulmonary vascular permeability in diabetic rats through activation of transient receptor potential melastatin 2 channels. Microcirculation 21: 754-760, 2014.

77. Palanivel R, Ganguly R, Turdi S, Xu A and Sweeney G: Adiponectin stimulates Rho-mediated actin cytoskeleton remodeling and glucose uptake via APPL1 in primary cardiomyocytes. Metabolism 63: 1363-1373, 2014

78. Diaz MB, Herzig S and Vegiopoulos A: Thermogenic adipocytes: From cells to physiology and medicine. Metabolism 63: 1238-1249, 2014

79. Sun L and Trajkovski M: MiR-27 orchestrates the transcriptional regulation of brown adipogenesis. Metabolism 63 272-282, 2014

80. Hondares E, Gallego-Escuredo JM, Flachs P, Frontini A, Cereijo R, Goday A, Perugini J, Kopecky P, Giralt M, Cinti S, et al: Fibroblast growth factor-21 is expressed in neonatal and pheochromocytoma-induced adult human brown adipose tissue. Metabolism 63: 312-317, 2014.

81. Boström PA, Fernández-Real JM and Mantzoros C: Irisin in humans: Recent advances and questions for future research. Metabolism 63: 178-180, 2014.

82. Tsuchiya Y, Ando D, Takamatsu K and Goto K: Resistance exercise induces a greater irisin response than endurance exercise. Metabolism 64: 1042-1050, 2015.

83. Sharma AM, Janke J, Gorzelniak K, Engeli S and Luft FC: Angiotensin blockade prevents type 2 diabetes by formation of fat cells. Hypertension 40: 609-611, 2002.

84. Santos SH, Braga JF, Mario EG, Pôrto LC, Rodrigues-Machado Mda G, Murari A, Botion LM, Alenina N, Bader M and Santos RA: Improved lipid and glucose metabolism in transgenic rats with increased circulating angiotensin-(1-7). Arterioscler Thromb Vasc Biol 30: 953-961, 2010. 